\title{
Detection of quantitative trait loci for growth and fatness in pigs
}

\author{
Jean-Pierre BIDANEL $^{\mathrm{a}, *}$, Denis MILAN ${ }^{\mathrm{b}}$, \\ Nathalie IANnuCCelli ${ }^{\mathrm{b}}$, Yves Amigues ${ }^{\mathrm{c}}$, \\ Marie-Yvonne Boscher ${ }^{\mathrm{c}}$, Florence Bourgeois ${ }^{\mathrm{c}}$, \\ Jean-Claude CARITEz ${ }^{\mathrm{d}}$, Joseph GRUAND ${ }^{\mathrm{e}}$, \\ Pascale Le RoY ${ }^{\mathrm{a}}$, Hervé LAGANT ${ }^{\mathrm{a}}$, \\ Raquel Quintanilla ${ }^{\mathrm{a}, * *}$, Christine Renard ${ }^{\mathrm{f}}$, \\ Joël Gellin $^{\mathrm{b}}$, Louis Ollivier ${ }^{\mathrm{a}}$, Claude Chevalet $^{\mathrm{b}}$ \\ Institut national de la recherche agronomique, France \\ a Station de génétique quantitative et appliquée, 78352 Jouy-en-Josas Cedex, \\ ${ }^{\mathrm{b}}$ Laboratoire de génétique cellulaire, 31326 Castanet Tolosan Cedex \\ ${ }^{c}$ Labogéna, 78352 Jouy-en-Josas Cedex \\ d Domaine expérimental du Magneraud, 17700 Surgères \\ e Station expérimentale de sélection porcine, 86480 Rouillé \\ ${ }^{\mathrm{f}}$ Laboratoire de radiobiologie et d'étude du génome, 78352 Jouy-en-Josas Cedex
}

(Received 27 October 2000; accepted 11 January 2001)

\begin{abstract}
A quantitative trait locus (QTL) analysis of growth and fatness data from a threegeneration experimental cross between Meishan (MS) and Large White (LW) pig breeds is presented. Six boars and $23 \mathrm{~F} 1$ sows, the progeny of six LW boars and six MS sows, produced $530 \mathrm{~F} 2$ males and $573 \mathrm{~F} 2$ females. Nine growth traits, i.e. body weight at birth and at 3, 10, 13, 17 and 22 weeks of age, average daily gain from birth to 3 weeks, from 3 to 10 weeks and from 10 to 22 weeks of age, as well as backfat thickness at 13, 17 and 22 weeks of age and at 40 and $60 \mathrm{~kg}$ live weight were analysed. Animals were typed for a total of 137 markers covering the entire porcine genome. Analyses were performed using two interval mapping methods: a linecross (LC) regression method where founder lines were assumed to be fixed for different QTL alleles and a half-/full-sib (HFS) maximum likelihood method where allele substitution effects were estimated within each half-/full-sib family. Both methods revealed highly significant gene effects for growth on chromosomes 1, 4 and 7 and for backfat thickness on chromosomes 1 , 4, 5, 7 and $\mathrm{X}$, and significant gene effects on chromosome 6 for growth and backfat thickness. Suggestive QTLs were also revealed by both methods on chromosomes 2 and 3 for growth and 2 for backfat thickness. Significant gene effects were detected for growth on chromosomes 11 ,
\end{abstract}

\footnotetext{
* Correspondence and reprints

E-mail: bidanel@dga.jouy.inra.fr

** On leave from: Departamento de Producción Agraria, Universidad Pública de Navarra, Pamplona, Spain
} 
13, 14, 16 and 18 and for backfat thickness on chromosome 8, 10, 13 and 14. LW alleles were associated with high growth rate and low backfat thickness, except for those of chromosome 7 and to a lesser extent early-growth alleles on chromosomes 1 and 2 and backfat thickness alleles on chromosome 6.

pig / gene mapping / quantitative trait locus / growth / fatness

\section{INTRODUCTION}

Genetic maps of the porcine genome have been developed during the last decade [3,10,32,33]. More than 3800 markers, including 1500 microsatellites (M. Rothschild, personal communication), spaced throughout the genome, are currently available. These genetic maps have made it possible to perform a systematic search of individual loci affecting quantitative traits of economic importance.

An experiment was conducted at INRA to map loci affecting a number of economically important traits in a Meishan $\times$ Large White F2 population using microsatellite markers. The large differences observed between both breeds in growth performance, body composition, meat quality, reproduction and behaviour (e.g. [4]) make it likely that a number of genes with large and intermediate effects are segregating in second generation crosses. A genomewide scan using a panel of 137 markers was performed in a Meishan $\times$ Large White crossbred population with 530 males and 573 female F2 progeny. This paper reports the results obtained for growth rate and backfat thickness.

\section{MATERIALS AND METHODS}

\subsection{Animals and data recording}

A three-generation resource population was developed at the INRA experimental research farm of Le Magneraud (Surgères, Charente-Maritime, hereafter referred to as Le Magneraud) firstly by mating six unrelated Large White boars to six loosely related Meishan sows (one boar/sow). One boar and four gilts were kept for breeding from each of the six litters produced (except in one litter where only three females were available). Three or four F1 females were assigned to each $\mathrm{F} 1$ boar and were mated to produce the largest possible families of F2 piglets. Assignments were performed to minimise relationships. Six F1 females were culled early and were removed from the experiment. The 17 remaining sows were allowed to produce up to 13 litters. Two of the six males were culled before the end of the experiment. Their females were reassigned to the four remaining males in order to produce new full-sib families. A total of $573 \mathrm{~F} 2$ female and $530 \mathrm{~F} 2$ male pigs were used for quantitative trait locus (QTL) mapping. The sibship structure of the F2 population is shown in Table I. 
Table I. Distribution of F2 pigs in full-sib families. Number of male (M) and female (F) offspring per sire (sires are numbered from 1 to 6 and lines in the table correspond to the respective full-sib families).

\begin{tabular}{lccccccccccccc}
\hline Sire & \multicolumn{1}{c}{} & \multicolumn{1}{c}{${ }^{2}$} & \multicolumn{3}{c}{3} & \multicolumn{1}{c}{5} & \multicolumn{2}{c}{6} \\
Sex & M & F & M & F & M & F & M & F & M & F & M & F \\
\hline & 49 & 53 & 18 & 19 & 32 & 16 & 33 & 22 & 26 & 28 & 19 & 43 \\
& 19 & 19 & 15 & 13 & 10 & 16 & 13 & 14 & 36 & 14 & 30 & 37 \\
& 22 & 21 & 26 & 12 & 12 & 17 & 14 & 11 & 24 & 51 & 29 & 24 \\
& 12 & 24 & 19 & 18 & 7 & 10 & 18 & 23 & 31 & 37 & & \\
& & & & & & & & & 16 & 31 & & \\
\hline Total (per sex/sire) & 102 & 117 & 78 & 62 & 61 & 59 & 78 & 70 & 133 & 161 & 78 & 104 \\
\hline Total (per sire) & 219 & 140 & 120 & 148 & 294 & & 182 \\
\hline
\end{tabular}

The 12 founder animals were tested and were found to be free of the mutation at the ryanodine receptor locus which is responsible for halothane susceptibility.

The sows were managed under a batch farrowing system, with a 3-week interval between contiguous batches. These batches then became postweaning and fattening batches of growing pigs. All piglets were individually weighed at birth and at 3 weeks of age. Piglets were weaned at 28 days of age and placed in collective pens in the postweaning unit until 10 weeks of age. Male piglets were not castrated and were transferred at 10 weeks of age to another INRA experimental herd (SESP, Rouillé, Vienne, hereafter referred to as Rouillé). Conversely, female piglets were raised in Le Magneraud, with the exception of 68 females raised in Rouillé in 1992.

When arriving in Rouillé, male piglets were allotted to pens of about 10 animals in a semi-open building. They were given an ad libitum diet containing $17 \%$ crude protein, $0.85 \%$ lysine and $3100 \mathrm{kcal}$ digestible energy during the whole testing period from 10 to 22 weeks of age. They were weighed at the beginning and at the end of the testing period. They were also weighed and measured for backfat thickness at 13 and 17 weeks of age. Six ultrasonic backfat measurements were taken on each side of the spine, $4 \mathrm{~cm}$ from the mid-dorsal line at the levels of the shoulder, the last rib and the hip joint, respectively. Females were also allotted to pens of about ten animals in a closed building and were performance tested between 10 and 22 weeks of age. They were given an ad libitum diet with the same characteristics as the male diet during the whole testing period. They were weighed at 10,13, 17 and 22 weeks of age and measured for backfat thickness at 13, 17 and 22 weeks of age. Backfat measurement sites were the same as for males. 
Table II. Overall means and phenotypic standard deviations of the 14 traits studied.

\begin{tabular}{|c|c|c|c|}
\hline Trait & $\begin{array}{l}\text { Number } \\
\text { of pigs }\end{array}$ & Mean & Standard deviation \\
\hline \multicolumn{4}{|l|}{ Body weight (kg) at: } \\
\hline - birth (WB) & 1090 & 1.23 & 0.24 \\
\hline-3 weeks of age (W3w) & 1090 & 5.43 & 0.90 \\
\hline - 10 weeks of age (W10w) & 1090 & 25.2 & 3.3 \\
\hline - 13 weeks of age (W13w) & 1081 & 38.2 & 4.9 \\
\hline - 17 weeks of age (W17w) & 1081 & 55.2 & 7.7 \\
\hline - 22 weeks of age (W22w) & 1055 & 76.1 & 9.4 \\
\hline \multicolumn{4}{|l|}{ Average daily gain $\left(\mathrm{g} \cdot \mathrm{d}^{-1}\right)$} \\
\hline - from birth to 3 weeks of age (ADG1) & 1090 & 209 & 44 \\
\hline - from 3 to 10 weeks of age (ADG2) & 1090 & 373 & 55 \\
\hline - from 10 to 22 weeks of age (ADG3) & 1053 & 620 & 110 \\
\hline \multicolumn{4}{|l|}{ Average backfat thickness (mm) at: } \\
\hline - 13 weeks of age (BF13w) & 1073 & 12.7 & 2.00 \\
\hline - 17 weeks of age (BF17w) & 1071 & 16.4 & 2.85 \\
\hline - 22 weeks of age $(B F 22 w)^{(a)}$ & 542 & 25.2 & 3.69 \\
\hline - $40 \mathrm{~kg}$ live weight (BF40kg) & 1073 & 12.7 & 1.80 \\
\hline - $60 \mathrm{~kg}$ live weight (BF60kg) & 1065 & 17.2 & 2.75 \\
\hline
\end{tabular}

(a) Measured in females only.

\subsection{Traits analysed}

With the exception of backfat thickness at 22 weeks of age, which was only measured in females, traits were measured in both sexes. A total of 14 traits were analysed, i.e.:

- weight at birth (WB), at 3 weeks (W3w), 10 weeks (W10w), 13 weeks (W13w), 17 weeks (W17w) and 22 weeks (W22w) of age;

- average daily gain from birth to 3 weeks of age (ADG1), from 3 to 10 weeks of age (ADG2), and from 10 to 22 weeks of age (ADG3);

- average backfat thickness at $14(\mathrm{BF} 14 \mathrm{w}), 17(\mathrm{BF} 17 \mathrm{w})$ and $22(\mathrm{BF} 22 \mathrm{w})$ weeks of age;

- average backfat thickness at 40 (BF40kg) and 60 (BF60kg) kg live weight.

The number of records, overall means and standard deviations of the 14 traits studied are shown in Table II.

\subsection{Genotyping}

The 1103 F2 pigs, their 29 parents and 12 grandparents were typed for 123 microsatellite markers and for the major histocompatibility complex (SLA). The panel was complemented by 13 additional microsatellite markers 
used in families with homozygous markers in QTL chromosomal regions. The microsatellite markers were selected from published linkage maps $[3,33]$ and from more recently developed markers at the INRA Laboratoire de génétique cellulaire according to their position, their heterozygozity as well as the quality and the reproducibility of their profile on automatic sequencers. The panel of markers covered all 18 autosomes and the $\mathrm{X}$ chromosome. The number of markers per chromosome varied between 3 (SSC 18) and 12 (SSC 7).

The DNA was isolated from blood and spleen tissue samples. Genotyping was partly performed at Labogena (Jouy-en-Josas, France) and partly at the Laboratoire de génétique cellulaire on automated sequencers (ABI; Perkin Elmer, Norwalk, CT). Two to ten markers were combined according to their size and amplification conditions and amplified by PCR in one or two multiplexes. PCR products of 8 to 12 markers were then combined on a single gel and analysed simultaneously on automated sequencers. The fragment length of the PCR products was determined using Genescan software (ABI; Perkin Elmer). The genotype of the animals was then automatically determined using Gemma [16] and Genotyper (ABI, Perkin Elmer) softwares. Genotype data were finally checked, validated and stored in the Gemma database [16].

\subsection{Statistical analyses}

Multipoint linkage analyses were carried out for males, females and both sexes with the 2.4 version of the CriMap software [11]. Recombination units were then converted into map distances using the Haldane mapping function.

Phenotypic data were first adjusted for systematic environmental effects. Adjustment factors were obtained using a mixed linear model [15], i.e. assuming a polygenic inheritance. The model used to describe the data was:

$$
\mathbf{y}=\mathbf{X b}+\mathbf{W p}+\mathbf{Z a}+\mathbf{e}
$$

where $\mathbf{y}$ is the vector containing the phenotypic data of F2 animals for a given trait, $\mathbf{b}$ is a vector containing fixed effects and covariables, $\mathbf{p}$ and $\mathbf{a}$ are vectors containing the random effects of common birth litter and the additive genetic value of each animal, respectively, and e is a random residual effect. The covariance structure of the random effects was assumed as follows: $\mathbf{p} \sim$ $N\left(\mathbf{0}, \mathbf{I} \sigma_{p}^{2}\right), \mathbf{a} \sim N\left(\mathbf{0}, \mathbf{A} \sigma_{a}^{2}\right), \mathbf{e} \sim N\left(\mathbf{0}, \mathbf{I} \sigma_{e}^{2}\right)$ and $\operatorname{cov}\left(\mathbf{a}, \mathbf{p}^{\prime}\right)=\operatorname{cov}\left(\mathbf{a}, \mathbf{e}^{\prime}\right)=$ $\operatorname{cov}\left(\mathbf{p}, \mathbf{e}^{\prime}\right)=\mathbf{0}$ where $N$ stands for a multivariate normal distribution, $\mathbf{I}$ is the identity matrix, $\mathbf{A}$ the additive relationship matrix, and $\sigma_{p}^{2}, \sigma_{a}^{2}, \sigma_{e}^{2}$ are litter, additive genetic and residual variances, respectively. The $\mathbf{b}$ vector included contemporary group and sex as fixed effects, and age at measurement and the size of birth litter (preweaning traits) as covariates. The data $\tilde{\mathbf{y}}$ used for QTL mapping were obtained as: $\tilde{\mathbf{y}}=\mathbf{y}-\mathbf{X} \hat{\mathbf{b}}-\mathbf{W} \hat{\mathbf{p}}$. Estimates of fixed effects $(\hat{\mathbf{b}})$ and of common birth litter effects $(\hat{\mathbf{p}})$ were obtained as backsolutions 
from restricted maximum likelihood analyses [29]. The computations were performed using the VCE software [25].

Two types of interval mapping analyses were performed: 1) a line-cross analysis which assumes that founder populations are fixed for different QTL alleles (hereafter referred to as the LC model); 2) a model assuming that the F2 population is a mixture of full and half-sib families and making no assumption about the number of QTL alleles and allele frequencies within the founder populations (hereafter referred to as the HFS model).

The LC analysis was performed using the software developed by Haley et al. [12]. The model used assumed that founder breeds were fixed for alternative alleles (e.g. Q in Meishan and q in Large White animals). Denoting the effects of QQ, Qq and qq as $a, d$ and $-a$, respectively, the adjusted performance $\tilde{y}_{i}$ of an F2 offspring $i$ could be written as:

$$
\tilde{y}_{i}=\mu+c_{a i} a+c_{d i} d+e_{i}
$$

where $\mu$ is the population mean, $c_{a i}$ and $c_{d i}$ are the coefficients of additive $(a)$ and dominance $(d)$ components, respectively, for animal $i$ at a given position, and $e_{i}$ is the residual error. $c_{a i}$ and $c_{d i}$ were computed as $c_{a i}=\operatorname{Prob}\left(\mathrm{QQ}_{i}\right)-\operatorname{Prob}\left(\mathrm{qq}_{i}\right)$ and $c_{d i}=\operatorname{Prob}\left(\mathrm{Qq}_{i}\right)$, where $\operatorname{Prob}\left(\mathrm{XX}_{i}\right)$ is the probability of animal $i$ having the genotype $\mathrm{XX}_{i}$. The genotype probabilities were computed as described in Haley et al. [12] considering only the most probable phases. At each location (each $\mathrm{cM}$ ), an $\mathrm{F}$ ratio was computed comparing the model with one QTL (1) to an equivalent model without any linked QTL. Estimates for $a$ and $d$ were calculated at the location with the highest $\mathrm{F}$ ratio.

In the HFS model, the F2 population was assumed to be structured into 24 full-sib families nested within 6 independent sire families. Hence, dams mated to different sires were considered as different dams. Genotype probabilities were computed in three successive steps [21]. First, sire genotype probabilities were computed conditional on grandparental, mate and progeny marker information assuming sire families to be half-sib families. Dam genotype probabilities were then computed conditional on sire genotype and grandparental and progeny marker information. Finally, transmission probability, i.e. the probability for each offspring to receive a given gamete from its sire and dam, was computed for each position along a chromosome, conditional on the grandparental origin of markers, sire and dam phases and marker genotypes of the individual.

The test statistic was computed as the ratio of likelihoods under the hypothesis of one (H1) vs. no (H0) QTL linked to the set of markers considered. Under the H1 hypothesis, a QTL with a gene substitution effect for each sire and each dam was fitted to the data. Sire genotypes were considered to be correctly rebuilt due to the large family size, so that only the most probable 
sire phase was considered. Conversely, all sufficiently probable (above 0.10) dam phases were considered, so that the likelihood $\Lambda$ could not be entirely linearised. Given these hypotheses, the likelihood at any location $x$ could be written as:

$$
\Lambda^{x}=\prod_{i, j} \sum_{h d_{i j}} p\left(h d_{i j} \mid M_{i}, \hat{h} s_{i}\right) \prod_{k} f\left(\tilde{y}_{i j k} \mid \hat{h} s_{i}, h d_{i j}, M_{i}\right)
$$

where: $\prod_{i, j}$ is a product over full-sib families, $\sum_{h d_{i j}}$ is a summation over dam phases with a probability greater than $0.10, \hat{h} s_{i}=\arg \max _{h s_{i}} p\left(h s_{i} \mid M_{i}\right)$, $p\left(h s_{i} \mid M_{i}\right)=$ linkage phase probability for sire $i$ given marker information $M_{i}$, $p\left(h d_{i j} \mid M_{i}, \hat{h} s_{i}\right)=$ linkage phase for dam $j$ given marker information $M_{i}$ and sire linkage phase, $f\left(\tilde{y}_{i j k} \mid \hat{h} s_{i}, h d_{i j}, M_{i}\right)=$ probability density function of the adjusted phenotype $\tilde{y}_{i j k}$ of the $k$ th offspring of the $j$ th dam and the $i$ th sire, conditional on the chromosome segments transmitted by the sire $\left(q_{s}\right)$ and the dam $\left(q_{d}\right) \cdot \tilde{y}_{i j k}$ is supposed to be normally distributed with mean

$$
\sum_{q_{s}=1}^{2} \sum_{q_{d}=1}^{2} p\left(d_{i j k}^{x}=\left(q_{s}, q_{d}\right) \mid h s_{i}, h d_{i j}, M_{i}\right)\left(\mu_{i}^{x q_{s}}+\mu_{i j}^{x q_{d}}\right)
$$

and a variance $\sigma_{i}^{2}$ defined within each sire family, where

$$
p\left(d_{i j k}^{x}=\left(q_{s}, q_{d}\right) \mid h s_{i}, h d_{i j}, M_{i}\right)
$$

is the transmission probability from parents $i$ and $j$ to offspring $k$, and $\mu_{i}^{x q_{s}}$ and $\mu_{i j}^{x q_{d}}$ can be parameterised as $\mu_{i(j)}^{x 1}=\mu_{i(j)}+\alpha_{i(j)}^{x} / 2$ and $\mu_{i(j)}^{x 2}=\mu_{i(j)}-\alpha_{i(j)}^{x} / 2, \alpha_{i}^{x}$ and $\alpha_{i j}^{x}$ being the within-half-sib and within-full-sib average QTL substitution effects. Average substitution effects, which in the present case are equivalent to additive values $(a)$, were hence estimated within each sire family as $\mu_{i}^{x 1}-\mu_{i}^{x 2}$ and within each dam family as $\mu_{i j}^{x 1}-\mu_{i j}^{x 2}$, and averaged over families.

The analyses for QTL on chromosome X were performed for each sex separately in order to take into account that: 1) F2 males carried only one copy of X chromosome from either Meishan or Large White grandparents, whereas F2 females received an additional copy of Meishan X chromosome, 2) the $X$ chromosome does not recombine in F1 boars. As a consequence, only substitution effects of alleles transmitted by F1 sows could be estimated.

Approximate confidence intervals of QTL position were determined empirically by the "drop-off" method [20]. As shown by e.g. Mangin et al. [22], this method tends to give underestimated confidence intervals.

Three significance levels, i.e. suggestive, genome-wide significant and highly significant linkages were defined as proposed by Lander and Kruglyak [20]. Suggestive linkage was defined as the probability of obtaining, by chance, one 
significant result per genome analysis. Considering that 19 independent chromosomes were analysed and assuming the number of significant chromosomes to follow a binomial distribution, the required threshold on a chromosome level $P_{\mathrm{c}}$ is such that $19 P_{\mathrm{c}}=1$, i.e. $P_{\mathrm{c}} \sim 0.05$ [19]. The chromosomal test significance level $P_{\mathrm{c}}$ corresponding to a genome-wide test probability $P_{\mathrm{g}}$ was obtained using the Bonferroni correction, i.e. as a solution to: $P_{\mathrm{g}}=1-\left(1-P_{\mathrm{c}}\right)^{19}$, which gives $P_{\mathrm{c}}=0.0027$ for $P_{\mathrm{g}}=0.05$ [19]. An equivalent number of independent traits was computed using canonical transformation [39] based on phenotypic correlation estimates in order to estimate the expected number of false positive results. The canonical transformation showed that the first six factors accounted for $96 \%$ of the total variation, so that $6,0.3$ and $6 \times 10^{-3}$ false-positives can be expected based on the above-mentioned suggestive, genome-wide significant and highly significant levels, respectively.

Significance thresholds were determined empirically by data permutation as described by Churchill and Doerge [6] for the line-cross analyses and by simulating the data assuming a polygenic infinitesimal model and a normal distribution of performance traits for the half-/full-sib analysis [21]. A total of 10000 to 50000 permutations or simulations were performed for each chromosome $\times$ trait combination. Estimated thresholds somewhat varied according to the chromosome and the trait investigated. They ranged from 5.4 to 5.8 and from 9.0 to 9.5 for suggestive and significant linkage, respectively, with LC model. Corresponding intervals with HFS model were 53.8-56.9 and $65.1-70.3$, respectively.

\section{RESULTS}

\subsection{Markers and genetic map}

The main characteristics of the panel of markers used and the distribution of the 137 markers used are shown in Table III and in Figure 1, respectively. It can be seen from Figure 1 and from the position of markers on published genetic maps [33] that the panel of markers used satisfactorily covers the 18 autosomes and the $\mathrm{X}$ chromosome. The average distance between adjacent markers ranged from 3 to $60 \mathrm{cM}$, with a mean value of $22.0 \mathrm{cM}$, on the sexaveraged map. These variations were due to the lack of useful markers in some regions, but also to discrepancies between distances estimated in the current experiment and distances in the published linkage maps on which our selection of markers was based. Nevertheless, the order of markers was similar to that published by Rohrer et al. [33]

The length of the genome covered by the marker panel was noticeably larger than that reported by Rohrer et al. [33] - 2593 vs. $2286 \mathrm{cM}$, i.e. $13 \%$ longer. The female map was $46 \%$ longer than the male map (3246vs. $2216 \mathrm{cM}$ ). Sex 
Table III. Characteristics of the panel of markers.

\begin{tabular}{lcccc}
\hline & Mean & Minimum & Maximum & Sum \\
\hline $\begin{array}{l}\text { Markers/chromosome } \\
\text { Alleles/marker }\end{array}$ & 7.2 & 3 & 12 & 137 \\
$\begin{array}{l}\text { Map size/chromosome (cM) } \\
\text { - Average map }\end{array}$ & 5.5 & 2 & 14 & 757 \\
- Male map & 136 & 89 & 197 & 2593 \\
- Female map & 117 & 57 & 197 & 2216 \\
Marker interval (cM) & 171 & 126 & 229 & 3246 \\
- Average map & & & & \\
- Male map & 22.0 & 1 & 60 & - \\
- Female map & 18.8 & 1 & 60 & - \\
\hline
\end{tabular}

differences in map length varied along the genome. They were sometimes very important, as in the extreme situation of the SW1632-S0382 interval on SSC 11 (7 $\mathrm{cM}$ in males $v s .88 \mathrm{cM}$ in females). In other regions, markers distances in males were occasionally larger than those in females (e.g. $62 \mathrm{vs.} 8 \mathrm{cM}$ between markers S0396 and S0113 on SSC 1).

\subsection{QTL mapping}

Results showing associations with at least a suggestive level of significance obtained using both line-cross and half-/full-sib models are given in Tables IV to VII. Values of the test statistics, corresponding significance levels and QTL positions are given in Tables IV for growth traits and in Table VI for backfat thickness. Estimates of additive genetic and dominance effects (LC model) and of additive genetic values (HFS model) are shown in Tables V and VII, for growth and fatness traits respectively.

\subsubsection{Growth}

Nine chromosomal regions reached genome-wide significance for at least one growth trait. Four of these regions located on chromosomes SSC 1, 4, 7 and 13 were highly significant $\left(P_{\mathrm{g}}<0.001\right)$. Results from LC and HFS analyses were very similar except for SSC 13. A QTL explaining 1 to 3\% of the phenotypic variance of body weights from 10 to 17 weeks of age was located at the end of the q arm of SSC 1. Meishan alleles had a favourable effect on the three weight measurements. A suggestive QTL was also evidenced for W22w, but at a different position on the chromosome (87vs. $175 \mathrm{cM})$ and with a favourable effect of Large White alleles. The most likely position of the SSC 4 QTL was in the interval between markers S0001 and SW1089. The 


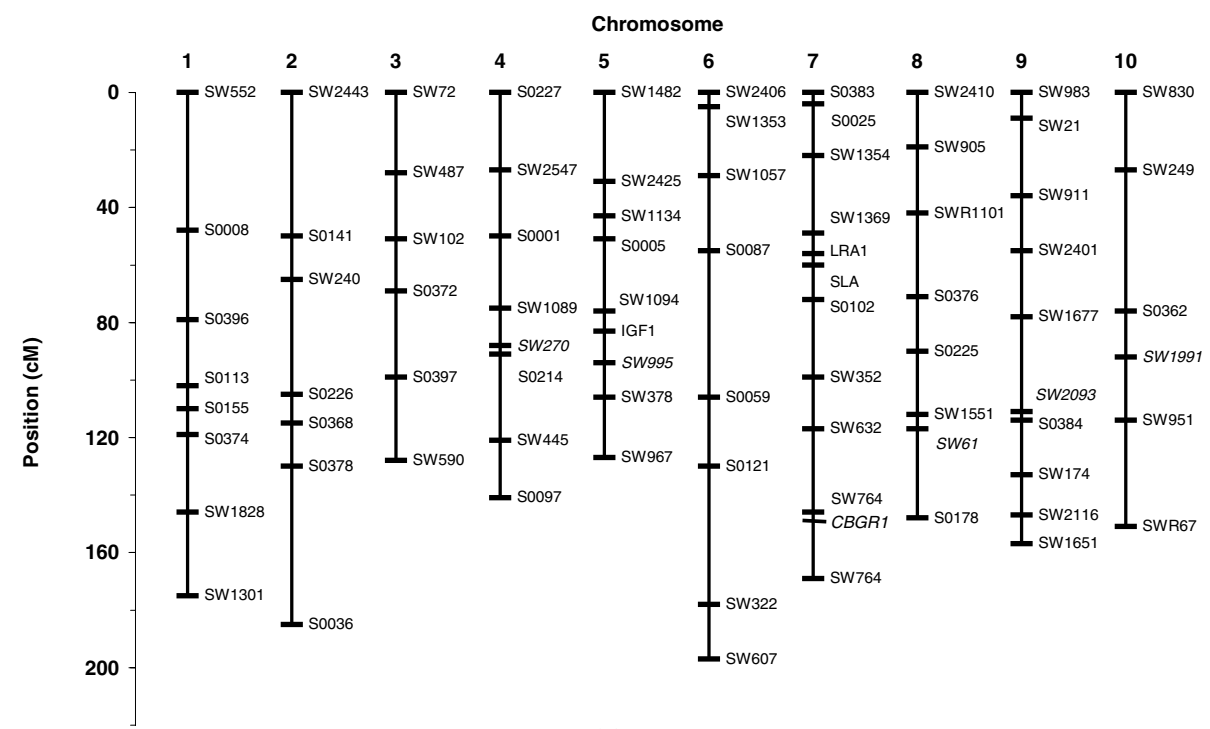

(a)

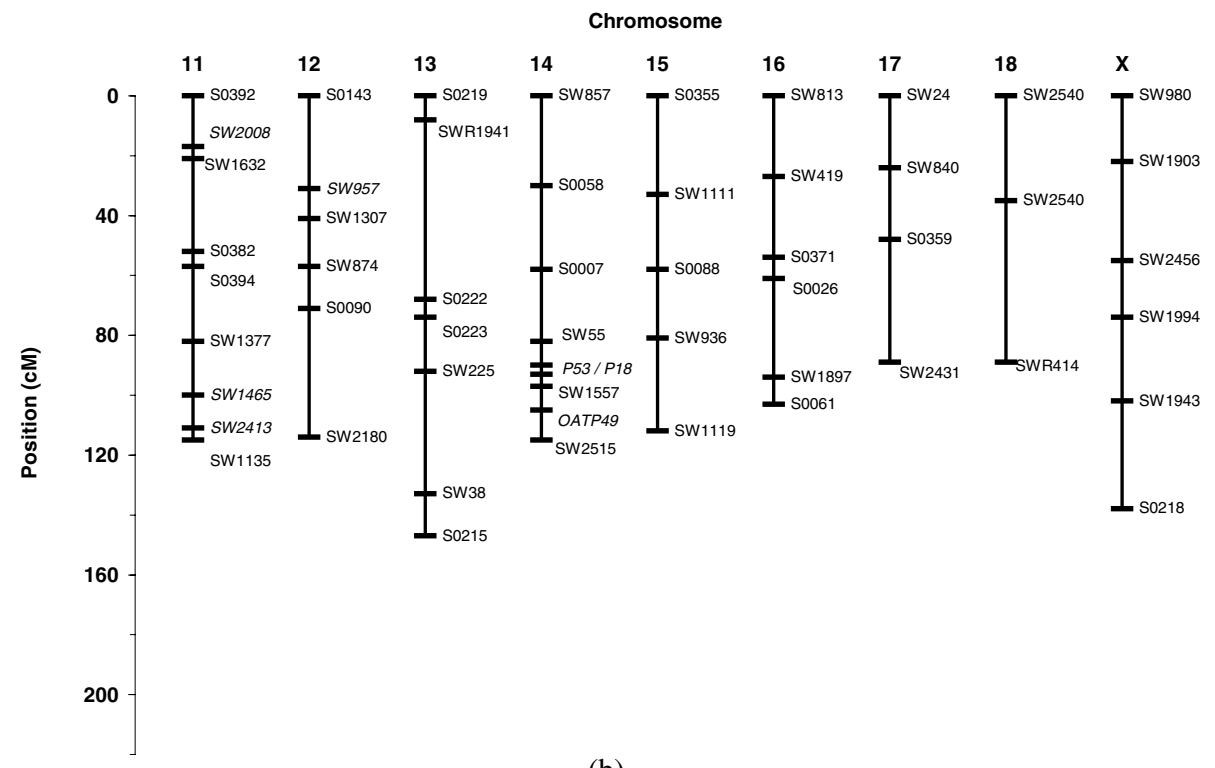

(b)

Figure 1. Sex average map of the panel of markers used. The 13 markers in italics were typed for a subset of F2 pigs (see text).

QTL mainly affected growth and body weights from 10 to 22 weeks of age and explained a fraction of phenotypic variance ranging from 4 (ADG3) to 7\% (W22w) of the phenotypic variance. The Meishan alleles decreased growth. No significant dominance effect was evidenced. The SSC 7 QTL was located 
Table IV. Results of QTL analyses for growth traits.

\begin{tabular}{|c|c|c|c|c|c|c|c|}
\hline \multirow[b]{2}{*}{ Trait $^{\mathrm{a}}$} & \multirow[b]{2}{*}{ SSC } & \multicolumn{3}{|c|}{ Line-cross model } & \multicolumn{3}{|c|}{ Half-full-sib model } \\
\hline & & $\begin{array}{c}\text { Position and } \\
\text { confidence interval } \\
\text { (cM) }\end{array}$ & F-ratio & $\begin{array}{c}\text { Significance } \\
\text { level }^{\mathrm{b}}\end{array}$ & $\begin{array}{l}\text { Position and } \\
\text { confidence } \\
\text { interval (cM) }\end{array}$ & $\mathrm{LR}^{\mathrm{c}}$ & $\begin{array}{c}\text { Significance } \\
\text { level }^{\mathrm{b}}\end{array}$ \\
\hline W10w & 1 & $175(159-175)$ & 12.6 & $* * *$ & $171(159-175)$ & 93.6 & $* * *$ \\
\hline W13w & 1 & $175(165-175)$ & 12.6 & $* * *$ & $169(154-175)$ & 88.8 & $* * *$ \\
\hline $\mathrm{W} 17 \mathrm{w}$ & 1 & $175(164-175)$ & 6.4 & + & $169(149-175)$ & 64.3 & + \\
\hline$W 22 \mathrm{~W}$ & 1 & $87(57-101)$ & 7.7 & + & - & - & $\mathrm{ns}$ \\
\hline ADG1 & 1 & $-{ }^{d}$ & - & $\mathrm{ns}$ & $163(147-175)$ & 57.4 & + \\
\hline $\mathrm{ADG} 2$ & 1 & $175(164-175)$ & 11.6 & $* *$ & $175(161-175)$ & 87.1 & $* * *$ \\
\hline $\mathrm{ADG} 2$ & 2 & $130(121-157)$ & 6.9 & + & $157(130-181)$ & 59.6 & + \\
\hline WB & 3 & - & - & $\mathrm{ns}$ & $27(7-37)$ & 57.3 & + \\
\hline $\mathrm{W} 22 \mathrm{~W}$ & 3 & $48(31-66)$ & 6.3 & + & $42(19-58)$ & 55.7 & + \\
\hline ADG3 & 3 & $52(35-67)$ & 7.0 & + & $42(18-59)$ & 54.7 & + \\
\hline WB & 4 & $70(57-79)$ & 11.9 & $* *$ & $63(31-86)$ & 56.7 & + \\
\hline W10w & 4 & $65(54-99)$ & 16.3 & $* * *$ & $78(32-87)$ & 68.5 & $*$ \\
\hline W13w & 4 & $70(57-79)$ & 28.3 & $* * *$ & $75(52-82)$ & 93.5 & $* * *$ \\
\hline W17w & 4 & $69(61-83)$ & 28.6 & $* * *$ & $74(52-80)$ & 92.1 & $* * *$ \\
\hline $\mathrm{W} 22 \mathrm{w}$ & 4 & $68(59-84)$ & 23.5 & $* * *$ & $60(46-78)$ & 99.8 & $* * *$ \\
\hline ADG1 & 4 & - & - & $\mathrm{ns}$ & $64(33-86)$ & 57.6 & + \\
\hline $\mathrm{ADG} 2$ & 4 & $65(57-98)$ & 14.0 & $* * *$ & $76(30-85)$ & 69.8 & $*$ \\
\hline $\mathrm{ADG} 3$ & 4 & $69(58-86)$ & 19.3 & $* * *$ & $61(48-77)$ & 96.5 & $* * *$ \\
\hline W10w & 6 & $132(124-154)$ & 8.1 & + & $70(37-101)$ & 61.2 & + \\
\hline W13w & 6 & $134(119-158)$ & 7.0 & + & $72(44-103)$ & 76.2 & $*$ \\
\hline W17w & 6 & $74(32-93)$ & 8.9 & + & $68(17-93)$ & 71.6 & $*$ \\
\hline$W 22 w$ & 6 & $78(25-105)$ & 6.7 & + & $78(38-126)$ & 59.9 & + \\
\hline ADG1 & 6 & $55(36-75)$ & 8.8 & + & $50(20-79)$ & 58.3 & + \\
\hline $\mathrm{ADG} 2$ & 6 & $130(119-150)$ & 6.9 & + & - & - & $\mathrm{ns}$ \\
\hline ADG3 & 6 & $81(55-115)$ & 7.2 & + & $78(10-121)$ & 55.9 & + \\
\hline WB & 7 & $57(52-82)$ & 9.4 & * & $70(56-94)$ & 59.0 & + \\
\hline W $3 w$ & 7 & $57(29-96)$ & 6.6 & + & - & - & $\mathrm{ns}$ \\
\hline W10w & 7 & $67(53-77)$ & 17.8 & $* * *$ & - & - & $\mathrm{ns}$ \\
\hline W13w & 7 & $67(61-73)$ & 25.3 & $* * *$ & $67(55-84)$ & 80.2 & $* * *$ \\
\hline $\mathrm{W} 17 \mathrm{~W}$ & 7 & $66(60-71)$ & 35.2 & $* * *$ & $66(59-73)$ & 113.0 & $* * *$ \\
\hline$W 22 w$ & 7 & $65(60-70)$ & 52.8 & $* * *$ & $66(58-73)$ & 124.9 & $* * *$ \\
\hline $\mathrm{ADG} 2$ & 7 & $69(62-77)$ & 18.0 & $* * *$ & - & - & ns \\
\hline ADG3 & 7 & $65(58-70)$ & 57.9 & $* * *$ & $66(59-73)$ & 139.3 & $* * *$ \\
\hline $\mathrm{W} 22 \mathrm{w}$ & 8 & $34(20-49)$ & 8.6 & + & - & - & $\mathrm{ns}$ \\
\hline ADG3 & 8 & $33(20-46)$ & 9.1 & $*$ & - & - & ns \\
\hline WB & 11 & - & - & $\mathrm{ns}$ & $71(41-94)$ & 67.6 & $*$ \\
\hline $\mathrm{ADG} 2)$ & 11 & $113(99-113)$ & 6.2 & + & - & - & $\mathrm{ns}$ \\
\hline $\mathrm{W} 17 \mathrm{w}$ & 12 & - & - & $\mathrm{ns}$ & $53(44-62)$ & 61.3 & + \\
\hline$W 22 w$ & 12 & $58(46-70)$ & 7.4 & + & - & - & $\mathrm{ns}$ \\
\hline ADG3 & 12 & $57(44-71)$ & 7.4 & + & - & - & ns \\
\hline W10w & 13 & $74(69-83)$ & 11.7 & $* *$ & - & - & ns \\
\hline W13w & 13 & $74(70-82)$ & 10.3 & $*$ & - & - & ns \\
\hline$W 22 w$ & 13 & $77(66-88)$ & 6.9 & + & - & - & ns \\
\hline $\mathrm{ADG} 2$ & 13 & $74(70-82)$ & 15.7 & $* * *$ & - & - & $\mathrm{ns}$ \\
\hline $\mathrm{ADG} 3$ & 13 & - & - & $\mathrm{ns}$ & $75(61-83)$ & 61.8 & + \\
\hline $\mathrm{W} 17 \mathrm{w}$ & 14 & $53(36-69)$ & 6.1 & + & - & - & $\mathrm{ns}$ \\
\hline W $3 w$ & 16 & $34(14-47)$ & 9.7 & + & - & - & $\mathrm{ns}$ \\
\hline ADG1 & 16 & $31(6-44)$ & 8.9 & + & - & - & ns \\
\hline $\mathrm{W} 17 \mathrm{w}$ & 18 & $5(0-26)$ & 64 & + & - & - & $\mathrm{ns}$ \\
\hline$W 22 w$ & 18 & $6(0-24)$ & 9.7 & $*$ & - & - & ns \\
\hline ADG3 & 18 & $9(0-26)$ & 8.7 & + & - & - & ns \\
\hline
\end{tabular}

${ }^{\mathrm{a}}$ See Table II for the definition of the traits. ${ }^{\mathrm{b}} * ; * ; * *=5 \%, 1 \%$ and $0.1 \%$ genome-wide significance levels, respectively + suggestive linkage. ${ }^{\mathrm{c}} \mathrm{LR}=$ likelihood ratio. ${ }^{\mathrm{d}}$ Not estimated 
Table V. Gene effects for growth traits (Meishan - Large White allele).

\begin{tabular}{|c|c|c|c|c|c|c|}
\hline \multirow[b]{2}{*}{ Trait $^{a}$} & \multirow[b]{2}{*}{ SSC } & \multicolumn{4}{|c|}{ Line-cross model } & \multirow{2}{*}{$\begin{array}{c}\text { HFS mode } \\
\text { Additive } \\
\text { value }\end{array}$} \\
\hline & & $\begin{array}{l}\text { Additive } \\
\text { value(a) }\end{array}$ & s.e.(a) & $\begin{array}{l}\text { Dominance } \\
\text { value (d) }\end{array}$ & s.e.(d) & \\
\hline W10w (kg) & 1 & 0.68 & 0.14 & -0.31 & 0.20 & 0.68 \\
\hline W13w (kg) & 1 & 0.98 & 0.21 & -0.64 & 0.31 & 0.94 \\
\hline W17w (kg) & 1 & 1.08 & 0.33 & -0.68 & 0.47 & 1.21 \\
\hline $\mathrm{W} 22 \mathrm{~W}(\mathrm{~kg})$ & 1 & -2.13 & 0.55 & -0.47 & 0.91 & ${ }_{-}^{1.1}$ \\
\hline $\mathrm{ADG} 1(\mathrm{~g})$ & 1 & $-{ }^{b}$ & - & - & - & 8 \\
\hline $\mathrm{ADG} 2(\mathrm{~g})$ & 1 & 10.6 & 2.4 & -5.9 & 3.4 & 9.5 \\
\hline $\mathrm{ADG} 2(\mathrm{~g})$ & 2 & 9 & 2 & 2 & 3 & 8 \\
\hline WB (g) & 3 & - & - & - & - & -4 \\
\hline $\mathrm{W} 22 \mathrm{~W}(\mathrm{~kg})$ & 3 & -0.63 & 0.51 & 1.01 & 0.76 & -0.89 \\
\hline $\mathrm{ADG} 3(\mathrm{~g})$ & 3 & -17 & 5 & 7 & 7 & -8 \\
\hline WB (g) & 4 & -46 & 10 & 1 & 15 & -58 \\
\hline W10w (kg) & 4 & -0.91 & 0.16 & 0.09 & 0.25 & -0.86 \\
\hline W13w (kg) & 4 & -1.69 & 0.23 & 0.16 & 0.35 & -1.67 \\
\hline W17w (kg) & 4 & -2.61 & 0.35 & 0.56 & 0.55 & -2.73 \\
\hline W22w (kg) & 4 & -3.50 & 0.52 & 1.00 & 0.82 & -3.71 \\
\hline $\mathrm{ADG} 1(\mathrm{~g})$ & 4 & - & - & - & - & -4 \\
\hline $\mathrm{ADG} 2(\mathrm{~g})$ & 4 & -13.9 & 2.6 & 2.1 & 4.3 & -13.5 \\
\hline ADG3 (g) & 4 & -31 & 5 & 10 & 8 & -33 \\
\hline W10w (kg) & 6 & -0.37 & 0.16 & 0.82 & 0.24 & -0.68 \\
\hline W13w (kg) & 6 & -0.77 & 0.25 & 0.85 & 0.39 & -1.05 \\
\hline $\mathrm{W} 17 \mathrm{w}(\mathrm{kg})$ & 6 & -1.75 & 0.43 & 0.90 & 0.83 & -1.70 \\
\hline W22w (kg) & 6 & -2.32 & 0.64 & 0.94 & 1.28 & -2.27 \\
\hline $\mathrm{ADG} 1(\mathrm{~g})$ & 6 & -7 & 2 & 1 & 2 & -7 \\
\hline $\mathrm{ADG} 2(\mathrm{~g})$ & 6 & -5 & 3 & 12 & 4 & - \\
\hline ADG3 (g) & 6 & -24 & 6 & 6 & 13 & -23 \\
\hline WB $(\mathrm{g})$ & 7 & 38 & 9 & 7 & 13 & 38 \\
\hline W3w (g) & 7 & 140 & 39 & 13 & 55 & - \\
\hline W10w (kg) & 7 & 0.67 & 0.15 & 0.90 & 0.23 & - \\
\hline $\mathrm{W} 13 \mathrm{w}(\mathrm{kg})$ & 7 & 1.24 & 0.22 & 1.52 & 0.34 & 1.16 \\
\hline $\mathrm{W} 17 \mathrm{w}(\mathrm{kg})$ & 7 & 2.32 & 0.34 & 2.54 & 0.52 & 2.47 \\
\hline W22W (kg) & 7 & 4.41 & 0.49 & 3.72 & 0.75 & 4.31 \\
\hline $\mathrm{ADG} 2(\mathrm{~g})$ & 7 & 10 & 2 & 16 & 4 & - \\
\hline ADG3 (g) & 7 & 46 & 5 & 35 & 7 & 44 \\
\hline W22W (kg) & 8 & -2.09 & 0.54 & 1.42 & 0.85 & - \\
\hline ADG3 (g) & 8 & -21 & 5 & 16 & 9 & - \\
\hline WB (g) & 11 & - & - & - & - & 10 \\
\hline $\mathrm{ADG} 2(\mathrm{~g})$ & 11 & -3 & 2 & 11 & 3 & -8 \\
\hline W17w (kg) & 12 & - & - & - & - & -1.25 \\
\hline W22w (kg) & 12 & -1.88 & 0.49 & -0.19 & 0.70 & - \\
\hline $\mathrm{ADG} 3(\mathrm{~g})$ & 12 & -18 & 5 & -5 & 7 & - \\
\hline W10w (kg) & 13 & 0.28 & 0.15 & 0.88 & 0.20 & - \\
\hline W13w (kg) & 13 & 0.24 & 0.22 & 1.32 & 0.31 & - \\
\hline $\mathrm{W} 22 \mathrm{w}(\mathrm{kg})$ & 13 & 0.20 & 0.52 & 2.79 & 0.76 & - \\
\hline $\mathrm{ADG} 2(\mathrm{~g})$ & 13 & 6 & 2 & 16 & 3 & - \\
\hline $\mathrm{ADG} 3(\mathrm{~g})$ & 13 & - & - & - & - & 5 \\
\hline W17w (kg) & 14 & -0.73 & 0.37 & 0.17 & 0.59 & - \\
\hline W3w (kg) & 16 & 0.09 & 0.05 & 0.31 & 0.08 & - \\
\hline $\mathrm{ADG} 1(\mathrm{~g})$ & 16 & 4 & 2 & 12 & 3 & - \\
\hline W17w (kg) & 18 & -1.29 & 0.36 & 0.13 & 0.56 & - \\
\hline W22w (kg) & 18 & -2.31 & 0.53 & -0.42 & 0.85 & - \\
\hline ADG3 (g) & 18 & -23 & 6 & 1 & 9 & - \\
\hline
\end{tabular}

${ }^{\mathrm{a}}$ See Table II for the definition of the traits. ${ }^{\mathrm{b}}$ Not estimated. 
Table VI. Results of QTL analyses for fatness traits.

\begin{tabular}{|c|c|c|c|c|c|c|c|}
\hline \multirow[b]{2}{*}{ Trait $^{\mathrm{a}}$} & \multirow[b]{2}{*}{$\mathrm{SSC}$} & \multicolumn{3}{|c|}{ Line-cross model } & \multicolumn{3}{|c|}{ Half-/full-sib model } \\
\hline & & $\begin{array}{c}\text { Position and } \\
\text { confidence interval } \\
\text { (cM) }\end{array}$ & F-ratio & $\begin{array}{l}\text { Significance } \\
\text { level }^{\mathrm{b}}\end{array}$ & $\begin{array}{l}\text { Position and } \\
\text { confidence } \\
\text { interval }(\mathrm{cM})\end{array}$ & $\mathrm{LR}^{\mathrm{c}}$ & $\begin{array}{l}\text { Significance } \\
\text { level }^{\mathrm{b}}\end{array}$ \\
\hline $\mathrm{BF} 13 \mathrm{w}$ & 1 & $175(167-175)$ & 43.2 & $* * *$ & $172(162-175)$ & 156.3 & $* * *$ \\
\hline $\mathrm{BF} 17 \mathrm{w}$ & 1 & $175(167-175)$ & 36.6 & $* * *$ & $175(163-175)$ & 133.1 & $* * *$ \\
\hline $\mathrm{BF} 22 \mathrm{w}$ & 1 & $175(161-175)$ & 12.6 & $* * *$ & $172(161-175)$ & 82.7 & $* * *$ \\
\hline $\mathrm{BF} 40 \mathrm{~kg}$ & 1 & $175(166-175)$ & 31.4 & $* * *$ & $171(161-175)$ & 108.5 & $* * *$ \\
\hline $\mathrm{BF} 60 \mathrm{~kg}$ & 1 & $175(165-175)$ & 24.3 & $* * *$ & $175(163-175)$ & 99.8 & $* * *$ \\
\hline $\mathrm{BF} 13 \mathrm{w}$ & 2 & $0(0-24)$ & 7.5 & + & $10(0-60)$ & 56.8 & + \\
\hline $\mathrm{BF} 40 \mathrm{~kg}$ & 2 & $0(0-25)$ & 8.0 & + & $3(0-26)$ & 65.6 & + \\
\hline $\mathrm{BF} 60 \mathrm{~kg}$ & 2 & $0(0-24)$ & 7.7 & + & $1(0-26)$ & 61.9 & + \\
\hline $\mathrm{BF} 40 \mathrm{~kg}$ & 4 & $62(49-84)$ & 15.3 & $* * *$ & $62(55-82)$ & 88.8 & $* * *$ \\
\hline $\mathrm{BF} 60 \mathrm{~kg}$ & 4 & $72(59-84)$ & 14.9 & $* * *$ & $63(55-84)$ & 70.6 & $*$ \\
\hline $\mathrm{BF} 13 \mathrm{w}$ & 5 & $35(20-46)$ & 8.3 & + & $-{ }^{d}$ & - & $\mathrm{ns}$ \\
\hline $\mathrm{BF} 17 \mathrm{w}$ & 5 & $41(33-48)$ & 15.1 & $* * *$ & $43(34-49)$ & 60.8 & + \\
\hline $\mathrm{BF} 40 \mathrm{~kg}$ & 5 & $37(26-45)$ & 13.4 & $* * *$ & $43(33-50)$ & 58.6 & + \\
\hline $\mathrm{BF} 60 \mathrm{~kg}$ & 5 & $42(36-49)$ & 23.2 & $* * *$ & $43(36-48)$ & 87.1 & $* * *$ \\
\hline $\mathrm{BF} 13 \mathrm{w}$ & 6 & $61(43-77)$ & 11.9 & $* *$ & $121(108-152)$ & 68.0 & $*$ \\
\hline $\mathrm{BF} 17 \mathrm{w}$ & 6 & $63(37-81)$ & 9.9 & $*$ & $28(14-82)$ & 68.3 & $*$ \\
\hline $\mathrm{BF} 40 \mathrm{~kg}$ & 6 & $60(41-76)$ & 10.5 & $*$ & - & - & ns \\
\hline $\mathrm{BF} 60 \mathrm{~kg}$ & 6 & $57(35-75)$ & 8.8 & + & - & - & ns \\
\hline $\mathrm{BF} 13 \mathrm{w}$ & 7 & $65(57-72)$ & 29.9 & $* * *$ & $69(56-80)$ & 90.4 & $* * *$ \\
\hline $\mathrm{BF} 17 \mathrm{w}$ & 7 & $58(51-68)$ & 30.0 & $* * *$ & $73(63-84)$ & 94.6 & $* * *$ \\
\hline $\mathrm{BF} 22 \mathrm{w}$ & 7 & $57(51-67)$ & 35.6 & $* * *$ & $73(63-84)$ & 92.2 & $* * *$ \\
\hline $\mathrm{BF} 40 \mathrm{~kg}$ & 7 & $65(57-71)$ & 75.7 & $* * *$ & $67(61-73)$ & 182.6 & $* * *$ \\
\hline $\mathrm{BF} 60 \mathrm{~kg}$ & 7 & $62(55-68)$ & 87.5 & $* * *$ & $66(58-72)$ & 189.8 & $* * *$ \\
\hline $\mathrm{BF} 13 \mathrm{w}$ & 8 & $49(24-63)$ & 6.3 & + & - & - & ns \\
\hline $\mathrm{BF} 40 \mathrm{~kg}$ & 8 & $33(21-57)$ & 9.5 & $*$ & - & - & ns \\
\hline $\mathrm{BF} 13 \mathrm{w}$ & 10 & - & - & $\mathrm{ns}$ & $140(115-151)$ & 64.4 & + \\
\hline $\mathrm{BF} 17 \mathrm{w}$ & 10 & - & - & ns & $130(103-151)$ & 58.0 & + \\
\hline $\mathrm{BF} 60 \mathrm{~kg}$ & 10 & - & - & ns & $130(92-151)$ & 58.4 & + \\
\hline $\mathrm{BF} 13 \mathrm{w}$ & 13 & $47(32-84)$ & 7.4 & + & - & - & ns \\
\hline $\mathrm{BF} 17 \mathrm{w}$ & 13 & - & - & ns & $71(42-82)$ & 60.3 & + \\
\hline $\mathrm{BF} 13 \mathrm{w}$ & 14 & - & - & $\mathrm{ns}$ & $19(4-45)$ & 60.0 & + \\
\hline $\mathrm{BF} 17 \mathrm{w}$ & 14 & - & - & ns & $16(4-28)$ & 69.0 & + \\
\hline $\mathrm{BF} 13 \mathrm{w}^{\mathrm{e}}$ & $\mathrm{X}$ & $74(69-84)$ & 31.8 & $* * *$ & $80(71-88)$ & 112.6 & $* * *$ \\
\hline $\mathrm{BF} 17 \mathrm{w}^{\mathrm{e}}$ & $\mathrm{X}$ & $73(68-85)$ & 31.6 & $* * *$ & $78(69-89)$ & 91.6 & $* * *$ \\
\hline$B F 22 w$ & $\mathrm{X}$ & $73(65-84)$ & 27.8 & $* * *$ & $77(70-87)$ & 96.3 & $* * *$ \\
\hline $\mathrm{BF} 40 \mathrm{~kg}^{\mathrm{e}}$ & $\mathrm{X}$ & $74(68-85)$ & 45.3 & $* * *$ & $83(76-90)$ & 155.1 & $* * *$ \\
\hline $\mathrm{BF} 60 \mathrm{~kg}^{\mathrm{e}}$ & $\mathrm{X}$ & $74(69-84)$ & 35.7 & $* * *$ & $81(68-89)$ & 119.2 & $* * *$ \\
\hline
\end{tabular}

${ }^{\mathrm{a}}$ See Table II for the definition of the traits. ${ }^{\mathrm{b}} * ; * ; * * *=5 \%, 1 \%$ and $0.1 \%$ genome-wide significance levels, respectively. $+=$ suggestive linkage. ${ }^{\mathrm{c}} \mathrm{LR}=$ likelihood ratio. ${ }^{\mathrm{d}}$ Not estimated. ${ }^{\mathrm{e}}$ In males only.

in the SLA-S0102 interval and explained 9 and $11 \%$ of the phenotypic variance of ADG3 and W22w, respectively. The Meishan alleles were associated with a higher growth rate and were almost completely dominant over Large White alleles. The SSC 13 QTL was overdominant for ADG2, with the estimate of $d$ being 2.5 larger than that of $a$.

Five other chromosomes, i.e. SSC 6, 8, 11, 16 and 18 presented genome-wide significance $\left(P_{\mathrm{g}}<0.05\right)$ for at least one growth trait. The LC and HFS models gave less consistent results than for highly significant QTLs. For instance, the most likely position of the SSC 6 QTL varied according to the trait and the 
Table VII. Gene effects for backfat thickness (Meishan - Large White) (mm).

\begin{tabular}{|c|c|c|c|c|c|c|}
\hline \multirow[b]{2}{*}{ Trait $^{\mathbf{a}}$} & \multirow[b]{2}{*}{$\mathrm{SSC}$} & \multicolumn{4}{|c|}{ Line-cross model } & \multirow{2}{*}{$\begin{array}{c}\text { HFS model } \\
\begin{array}{l}\text { Additive } \\
\text { effect (a) }\end{array}\end{array}$} \\
\hline & & $\begin{array}{l}\text { Additive } \\
\text { value (a) }\end{array}$ & s.e.(a) & $\begin{array}{l}\text { Dominance } \\
\text { value (d) }\end{array}$ & s.e.(d) & \\
\hline $\mathrm{BF} 13 \mathrm{w}$ & 1 & 0.71 & 0.09 & -0.56 & 0.12 & 0.63 \\
\hline $\mathrm{BF} 17 \mathrm{w}$ & 1 & 0.92 & 0.12 & -0.71 & 0.17 & 0.80 \\
\hline $\mathrm{BF} 22 \mathrm{w}$ & 1 & 1.10 & 0.23 & -0.53 & 0.33 & 0.73 \\
\hline $\mathrm{BF} 40 \mathrm{~kg}$ & 1 & 0.54 & 0.08 & -0.45 & 0.11 & 0.47 \\
\hline $\mathrm{BF} 60 \mathrm{~kg}$ & 1 & 0.73 & 0.12 & -0.59 & 0.17 & 0.58 \\
\hline $\mathrm{BF} 13 \mathrm{w}$ & 2 & 0.35 & 0.09 & -0.07 & 0.13 & 0.20 \\
\hline $\mathrm{BF} 40 \mathrm{~kg}$ & 2 & 0.32 & 0.08 & -0.12 & 0.12 & 0.26 \\
\hline $\mathrm{BF} 60 \mathrm{~kg}$ & 2 & 0.47 & 0.12 & -0.19 & 0.18 & 0.34 \\
\hline $\mathrm{BF} 40 \mathrm{~kg}$ & 4 & 0.50 & 0.09 & 0.01 & 0.15 & 0.52 \\
\hline $\mathrm{BF} 60 \mathrm{~kg}$ & 4 & 0.68 & 0.13 & -0.10 & 0.19 & 0.78 \\
\hline $\mathrm{BF} 13 \mathrm{w}$ & 5 & 0.40 & 0.10 & -0.12 & 0.15 & $-{ }^{b}$ \\
\hline $\mathrm{BF} 17 \mathrm{w}$ & 5 & 0.72 & 0.13 & -0.19 & 0.19 & 0.88 \\
\hline $\mathrm{BF} 40 \mathrm{~kg}$ & 5 & 0.45 & 0.09 & -0.12 & 0.13 & 0.48 \\
\hline $\mathrm{BF} 60 \mathrm{~kg}$ & 5 & 0.86 & 0.13 & -0.05 & 0.18 & 0.95 \\
\hline$B F 13 w$ & 6 & -0.37 & 0.10 & -0.46 & 0.16 & -0.21 \\
\hline $\mathrm{BF} 17 \mathrm{w}$ & 6 & -0.51 & 0.14 & -0.59 & 0.24 & -0.39 \\
\hline $\mathrm{BF} 40 \mathrm{~kg}$ & 6 & -0.25 & 0.09 & -0.48 & 0.14 & - \\
\hline $\mathrm{BF} 60 \mathrm{~kg}$ & 6 & -0.29 & 0.12 & -0.63 & 0.18 & - \\
\hline $\mathrm{BF} 13 \mathrm{w}$ & 7 & -0.71 & 0.09 & -0.21 & 0.14 & -0.67 \\
\hline $\mathrm{BF} 17 \mathrm{w}$ & 7 & -0.92 & 0.12 & -0.37 & 0.18 & -0.76 \\
\hline $\mathrm{BF} 22 \mathrm{w}$ & 7 & -1.89 & 0.22 & -0.16 & 0.31 & -1.42 \\
\hline $\mathrm{BF} 40 \mathrm{~kg}$ & 7 & -0.94 & 0.08 & -0.45 & 0.12 & -0.88 \\
\hline $\mathrm{BF} 60 \mathrm{~kg}$ & 7 & -1.47 & 0.12 & -0.79 & 0.18 & -1.34 \\
\hline $\mathrm{BF} 13 \mathrm{w}$ & 8 & 0.19 & 0.10 & 0.49 & 0.17 & - \\
\hline $\mathrm{BF} 40 \mathrm{~kg}$ & 8 & 0.30 & 0.09 & 0.41 & 0.14 & 0.20 \\
\hline $\mathrm{BF} 13 \mathrm{w}$ & 10 & - & - & - & - & 0.03 \\
\hline $\mathrm{BF} 17 \mathrm{w}$ & 10 & - & - & - & - & 0.22 \\
\hline $\mathrm{BF} 60 \mathrm{~kg}$ & 10 & - & - & - & - & 0.26 \\
\hline $\mathrm{BF} 13 \mathrm{w}$ & 13 & 0.15 & 0.13 & 0.93 & 0.26 & - \\
\hline $\mathrm{BF} 17 \mathrm{w}$ & 13 & - & - & - & - & 0.39 \\
\hline BF13w & 14 & - & - & - & - & 0.40 \\
\hline $\mathrm{BF} 17 \mathrm{w}$ & 14 & - & - & - & - & 0.41 \\
\hline $\mathrm{BF} 13 \mathrm{w}^{\mathrm{c}}$ & $\mathrm{X}$ & 1.68 & 0.11 & & & 1.50 \\
\hline $\mathrm{BF} 17 \mathrm{w}^{\mathrm{c}}$ & $\mathrm{X}$ & 2.05 & 0.14 & & & 1.93 \\
\hline $\mathrm{BF} 22 \mathrm{w}$ & $\mathrm{X}$ & 1.65 & 0.25 & & & 1.45 \\
\hline $\mathrm{BF} 40 \mathrm{~kg}^{\mathrm{c}}$ & $\mathrm{X}$ & 1.83 & 0.10 & & & 1.73 \\
\hline $\mathrm{BF} 60 \mathrm{~kg}^{\mathrm{c}}$ & $\mathrm{X}$ & 2.51 & 0.14 & & & 2.56 \\
\hline
\end{tabular}

${ }^{a}$ See Table II for the definition of the traits. ${ }^{b}$ Not estimated. ${ }^{c}$ In males only.

model used. The LC model detected a QTL between markers S0121 and SW322 for early growth traits (W10w, W13w and ADG2) and between markers S0087 and S0059, i.e. $60 \mathrm{cM}$ apart, for late growth traits (W17w, W22w and ADG3). Conversely, in the HFS model, a QTL was found between markers S0087 and S0059 for both early- and late-growth traits. The QTL explained about 3\% of the phenotypic variance of W17w, W22w and ADG3, with favourable effects of Large White alleles. Dominance effects were significant for early body weights (W10w, W13w) but not for late growth traits. The QTLs on SSC 8, 16 and 18 were only detected by the LC model. Conversely, the genome-wide significant QTL on SSC 11 was only found using the HFS model. Large White 
haplotypes in the SW905-SWR1101 region on SSC 8 and in the SW2540SW1984 region on SSC18 had favourable additive effects on ADG3 and W22w and no significant dominance effects. The QTLs located on SSC 11 and SSC 16 both appeared to have overdominant effects on preweaning growth.

Four additional chromosomal regions on SSC 2, 3, 12 and 14 reached a suggestive level of significance $\left(P_{\mathrm{c}}<0.05\right)$. Favourable effects of Large White alleles were obtained for W22w and ADG3 on SSC 3 and SSC 12 and for W17w on SSC 14, whereas Meishan alleles on SSC 2 were associated with a higher growth rate from 3 to 10 weeks of age.

\subsubsection{Fatness}

Seven different chromosomal regions reached genome-wide significance for fatness traits. Five of them were located on SSC 1, 4, 5, 7 and X were highly significant. The LC and HFS models gave very similar results for these five regions. Similarly, adjusting backfat measurements for either age or weight only had a limited influence on the results. The most likely position of the SSC 1, 4 and 7 QTLs were the same as those described here above for growth traits. SSC 5 and X QTLs were very close to markers SW1134 and SW1994, respectively. The chromosome X QTL was significant only in males, except at 22 weeks of age. SSC 1, 4, 5, 7 and X explained 4-6\%, 3-4\%, 2-5\%, 5-14\% and $8-40 \%$ of the phenotypic variance of backfat thickness traits respectively. Large White alleles from SSC 1, 4, 5 and X QTLs had favourable additive effects on backfat thickness. They were partially dominant over Meishan alleles on SSC 1, whereas SSC 4 and 5 QTLs had purely additive effects. Conversely, Meishan alleles were associated with lower backfat thickness on SSC 7 and were partially dominant over Large White alleles.

The two other regions reaching genome-wide significance $\left(P_{\mathrm{g}}<0.05\right)$ were located using the LC model on SSC 6 and SSC 8, respectively, in the same regions as those previously detected for W22w and ADG3. Both QTLs explained 1 to $2 \%$ of the phenotypic variance. Meishan alleles had an unfavourable additive effect on SSC 8, but a favourable effect on SSC 6 and were in both cases dominant over Large White alleles. Less consistent results were obtained using the HFS model, with no QTL (SSC 8) or variable positions (SSC 6) of the detected QTL.

Suggestive QTLs were detected on four additional chromosomes, i.e. SSC 2, 10,13 and 14. The SSC 2 QTL was located at the extremity of the p arm close to the IGF-2 locus. Favourable additive Large White alleles explained 1 to $2 \%$ of the phenotypic variance. Suggestive QTLs with favourable LW alleles were detected on SSC 13 using both the LC and HFS models, but on different traits $(\mathrm{BF} 13 \mathrm{w} v s . \mathrm{BF} 17 \mathrm{w})$ and at slightly different positions. The SSC 10 and SSC 14 regions were detected only with the HFS model. Favourable Large White alleles explained about $1 \%$ of the phenotypic variance. 


\section{DISCUSSION}

\subsection{Methodology}

The prior adjustment of the data for environmental effects was performed under the assumption of a polygenic infinitesimal model. Although the model is not appropriate when a QTL is segregating, it allowed adjusting the data for all fixed and random (birth litter) environmental effects, which was not possible with available QTL detection softwares. Various data adjustment procedures (no correction, correction for fixed effects prior to or within QTL mapping analyses, correction for fixed and random effects) were compared in preliminary analyses. Very similar results were obtained in all cases (with slightly lower likelihood ratios when using uncorrected data). This is not unexpected, as point estimates of fixed effects in univariate mixed linear models are not very sensitive to variations in the dispersion structure of random effects.

As emphasised by de Koning et al. [8], the use of both the line-cross (LC) and half-/full-sib (HFS) models allows to investigate different a priori assumptions about QTL genotypes in founder populations. The LC model $a$ priori assumes that different QTL alleles are fixed in founder populations. It is a very powerful model when this corresponds to the true state of nature, and it is rather robust to limited departures from this ideal situation, even though it tends to underestimate QTL effects in such situations [1]. The HFS model does not make any assumption about the number and frequency of QTL alleles in founder populations. It may thus be considered as a more general and realistic model, which will for instance be able to detect QTLs with similar allele frequencies in founder populations. Conversely, it involves a much larger number of parameters that require large full-sib families to be accurately estimated. Moreover, inferences about the number of alleles and their frequencies may become more complex. For instance, it was not possible to test the hypothesis of allele fixation in the parental population. Nevertheless, the similarity of the LC and HFS additive genetic effect estimates for the most important QTLs tends to indicate that different alleles were almost fixed in founder populations.

It should also be mentioned that the HFS model was probably slightly overparameterised in the present case, due to the limited number of founder animals and consequently founder alleles (a maximum of 24 assuming that all founder animals were unrelated). More parsimonious models considering the true pedigree structure of the population such as that developed by Pérez-Enciso and Varona [30] may be valuable.

Finally, the analyses were limited to the testing of a very simple genetic model, i.e. one vs. no QTL in a single-trait situation. More complex situations, such as models with two linked QTLs and models with imprinting effects, were presented for pigs by Knott et al. [19] and de Koning et al. [9], respectively, and might be worth exploring. The use of multiple trait models might also be 
useful to improve the analysis of correlated traits such as successive weight or backfat measurements and the test for pleiotropy or multiple linked QTLs. However, theoretical developments and experimental analyses have so far been limited $[5,18]$.

\subsection{QTL detected}

Results from the present study are consistent with those obtained in several experiments involving Chinese $\times$ White breed (generally Meishan $\times$ Large White) crosses. Backfat thickness genes were also mapped at the end of the q arm of SSC 1 by Rohrer and Keele [34] and de Koning et al. [8], on SSC 4 by Wang et al. [38] and Walling et al. [36], in the SLA region on SSC 7 with lean Chinese alleles by Rothschild et al. [35], Moser et al. [24], Rohrer and Keele [34], Wang et al. [38] and de Koning et al. [8], and on SSC X by Rohrer and Keele [34] and Harlizius et al. [14]. The latter authors obtained, as in present study, lower estimates of the SSC X QTL effects in females than in males in F2 pigs originating from Meishan grandsires and Large White granddams ( $v s$. Large White grandsires and Meishan granddam in the present study). The lower QTL effects in females thus cannot be explained by a dominant Meishan or Large White allele. As hypothesized by Harlizius et al. [14], it may be caused by random inactivation of the X chromosome in females or interactions with autosomal genes. The suggestive QTLs on SSC 2 and SSC 13 are located in the same chromosomal regions as those reported by de Koning et al. [8] and Yu et al. [40] respectively.

Similarly, growth gene results were consistent with those obtained in Chinese $\times$ White crossbred populations on SSC 1 by Paszek et al. [28] for early growth, on SSC 4 by Walling et al. [36] and Wang et al. [38], in the SLA region on SSC 7 with a fast-growth Meishan allele, by Rothschild et al. [35] and Wang et al. [38], and in the centre of SSC 13 by Yu et al. [40]. Walling et al. [36] also detected a QTL on SSC 7, but at a different position and with a favourable Large White allele.

Some QTLs were mapped in the same regions in other populations. Growth and backfat genes were mapped in the same regions of SSC 4 and SSC 13 in the Swedish QTL experiment based on a cross between the Wild Boar and Large White breeds $[2,23]$.

A joint analysis of chromosome 4 effects in several QTL experiments including the present experiment showed a gene effect on birth weight significant at the genome-wide level, though the effect was smaller and the gene was positioned slightly beyond the SW0189 marker [37]. The backfat gene detected in the Wild Boar $\times$ Large White crosses in the same joint analysis, also beyond SW0189, had a larger effect than that evidenced in Chinese $\times$ White breed crosses [37]. Backfat genes have been mapped in the same region IGF-2 of SSC 2 by Nezer et al. [26] in Piétrain $\times$ Large White crosses and by Jeon 
et al. [17] in Wild Boar $\times$ Large White crosses. Fatness QTLs have also been mapped on SSC 4 and SSC 6 in an Iberian $\times$ Landrace cross by Ovilo et al. [27] and Pérez-Enciso et al. [31]. The most likely position of the SSC 4 QTL was similar to that obtained in Meishan $\times$ Large White crosses. Conversely, the SSC 6 QTL was located about $40 \mathrm{cM}$ away from the most likely position of the QTL detected in the present study.

Previously undetected QTLs were detected for birth weight on SSC 11, for postweaning growth on SSC 16 and 18, and for backfat thickness on SSC 5. The SSC 18 QTL is located in the region of the leptin gene locus, which, using a candidate gene approach, has been shown to affect performance traits [13] and may thus be a positional candidate for this QTL, though no effect was detected on fatness traits. Conversely, it should be noted that the SSC 5 QTL is located more than $50 \mathrm{cM}$ away from the IGF-1 locus.

Several of the QTLs detected in this study affect different traits and have very close positions on the chromosomes. Although it may be reasonably hypothesised that in most cases a single QTL affects the different fatness traits or the most highly correlated growth traits, it is impossible to decide whether chromosomal regions affecting both growth and fatness traits are a single QTL with pleiotropic effects or several linked QTLs. The adjustment of backfat measurements for body weight has clearly shown that, in these situations, backfat QTLs are not a simple consequence of variation in the growth rate. Fine mapping studies allowing to separate closely linked chromosomal regions should provide an answer to this question.

Favourable (i.e. positive) effects on growth are generally, but not systematically associated with favourable (i.e. negative) effects on backfat thickness. This is not unexpected, as genetic correlations between growth and fatness traits are generally low in pigs ( -0.16 in the recent review of Clutter and Brascamp [7]).

\section{CONCLUSION}

With almost $1100 \mathrm{~F} 2$ pigs, the experiment analysed in the present paper is the largest pig genome scan analysed so far. It has confirmed the existence of and has somewhat more accurately positioned several previously mapped QTLs, and it has also detected several new QTLs. These QTLs are however generally mapped with low precision, making finer mapping studies necessary to reduce the mapping interval. Several applications of these results in the breeding industry may already be considered, such as the use of marker-assisted selection in Chinese $\times$ European synthetic lines, the choice of breeding animals in crossbreeding programs involving Chinese breeds or the introgression of high growth or leanness alleles in the Chinese breeds. Yet, further studies remain necessary to assess the genetic and economic impact of these new selection tools and to optimise their use. 


\section{ACKNOWLEDGEMENTS}

This experimental programme was funded by the European Union (Bridge and Biotech+ programs), INRA (Department of Animal Genetics and AIP "Structure des génomes animaux") and the "Groupement de recherches et d'études sur les génomes".

\section{REFERENCES}

[1] Alfonso L., Haley C.S., Power of different F2 schemes for QTL detection in livestock, Anim. Sci. 66 (1998) 1-8.

[2] Andersson L., Haley C.S., Ellegren H., Knott S.A., Johansson M., Andersson K., Andersson-Eklund L., Edfors-Lilja I., Fredholm M., Hansson I., Hakansson J., Lundström K., Genetic mapping of quantitative trait loci for growth and fatness in pigs, Science 263 (1994) 1771-1774.

[3] Archibald A.L., Brown J.F., Couperwhite S., Mc Queen H.A., Nicholson D., Haley C.S., Coppieters W., van de Weghe A., Stratil A., Wintero A.K., Fredholm M., Larsen N.J., Nielsen V.H., Milan D., Woloszyn N., Robic A., Dalens M., Riquet J., Gellin J., Caritez J.C., Hue D., Burgaud G., Ollivier L., Bidanel J.P., Vaiman M., Renard C., Geldermann H., Davoli R., Ruyter D., Versteger E.J.M., Groenen M.A.M., Davies W., Hoyheim B., Keiserud A., Andersson L., Ellegren H., Johansson M., Marklund L., Miller J.R., Anderson Dear D.V., Signer E., Jeffreys A.J., Moran C., Le Tissier P., Rothschild M.F., Tuggle C.K., Vaske D., Helm J., Liu H.C., Rahman A., Yu T.P., Larson R.G., Schmitz C.B., The PiGMaP consortium linkage map of the pig (Sus scrofa), Mamm. Genome 6 (1995) 157-175.

[4] Bidanel J.P., Caritez J.C., Legault C., Ten years of experiments with Chinese pigs in France. 1. Breed evaluation, Pig News Inf. 11 (1990) 345-348.

[5] Calinsky T., Kaszmarek Z., Krajewsky P., Frova C., Sari-Gorla M., A multivariate approach to the problem of QTL localization, Heredity 4 (2000) 303-310.

[6] Churchill G.A., Doerge R.W., Empirical threshold values for quantitative trait mapping, Genetics 138 (1994) 963-971.

[7] Clutter A.C., Brascamp E.W., Genetics of performance traits, in: The genetics of the pig, Rothschild M.F., Ruvinsky A. (Eds.), CAB International, 1998, pp. 427462.

[8] De Koning D.J., Janss L.L.G., Rattink A.P., van Oers P.A.M., de Vries B.J., Groenen M.A.M., van der Poel J.J., de Groot P.N., Brascamp E.W., van Arendonk J.A.M., Detection of quantitative trait loci for backfat thickness and intramuscular fat content in pigs (Sus scrofa), Genetics 152 (1999) 1679-1690.

[9] De Koning D.J., Rattink A.P., Harlizius B., van Arendonk J.A.M., Brascamp E.W., Groenen M.A.M., Genome-wide scan for body composition in pigs reveals important role of imprinting, Proc. Natl. Acad. Sci. USA 97 (2000) 7947-7950.

[10] Ellegren H., Chowdhary B., Johansson M., Andersson L., A primary linkage map of the porcine genome reveals a low rate of recombination, Genetics 137 (1994) 1089-1100. 
[11] Green P., Falls K., Crooks S., Documentation for CRIMAP version 2.4, Washington University School of Medicine, St. Louis (1990).

[12] Haley C.S., Knott S.A., Elsen J.M., Mapping quantitative trait loci in crosses between outbred lines using least squares, Genetics 136 (1994) 1195-1207.

[13] Hardge T., Köpke K., Wimmers K., Leuthold G., Association between polymorphism of the Leptin-gene (LEP) and performance traits in a porcine ressource family and in commercial outbred populations, in: Proceedings of the XXVI International Conference on Animal Genetics, 9-14 August 1998, Auckland, New Zealand, p. 106.

[14] Harlizius B., Rattink A.K., de Koning D.J., Faivre M., Joosten R.G., van Arendonk J.A.M., Groenen M.A.M., The X chromosome harbors quantitative trait loci for backfat thickness and intramuscular fat content in pigs, Mamm. Genome 11 (2000) 800-802.

[15] Henderson C.R., Sire evaluation and genetic trends, in: Proceedings of the Animal Breeding and Genetics Symposium in Honor of Dr J.L. Lush, American Society of Animal Science and Dairy Science Association, 1973, Champaign, Illinois, pp. 10-41.

[16] Iannuccelli E., Woloszyn N., Arhainx J., Gellin J., Milan D., GEMMA: a database to manage and automate microsatellite genotyping, Anim. Genet. 27 Suppl. 2 (1996) 55.

[17] Jeon J.T., Carlborg O., Törnsten A., Giuffra E., Amarger V., Chardon P., Andersson-Eklund L., Andersson K., Hansson I., Lundström K., Andersson L., A paternally expressed QTL affecting skeletal and cardiac muscle mass in pigs maps to the IGF2 locus, Nat. Genet. 21 (1999) 157-158.

[18] Jiang C., Zeng Z.B., Multiple trait analysis of genetic mapping for quantitative trait loci, Genetics 140 (1995) 1111-1127.

[19] Knott S.A., Marklund L., Haley C.S., Andersson K., Davies W., Ellegren H., Fredholm M., Hansson I., Hoyhem B., Lundström K., Moller M., Andersson L., Multiple marker mapping of quantitative trait loci in a cross between outbred Wild Boar and Large White pigs, Genetics 149 (1998) 1069-1080.

[20] Lander E.S., Kruglyak L., Genetic dissection of complex traits: guideliness for interpreting and reporting linkage results, Nat. Genet. 11 (1995) 241-247.

[21] Le Roy P., Elsen J.M., Boichard D., Mangin B., Bidanel J.P., Goffinet B., An algorithm for QTL detection in mixture of full and half sib families, in: Proceedings of the 6th World Congress on Genetics Applied to Livestock Production, 1998, Vol. 26, Armidale, pp. 257-260

[22] Mangin B., Goffinet B., Rebaï A., Constructing confidence intervals for QTL location, Genetics 138 (1994) 1301-1308.

[23] Marklund L., Nyström P.E., Stern S., Andersson-Eklund L., Andersson L., Confirmed quantitative trait loci for fatness and growth on pig chromosome 4, Heredity 82 (1999) 134-141.

[24] Moser G., Muller E., Beeckmann P., Yue G., Geldermann H., Mapping QTLs in F2 generations of Wild Boar, Pietrain and Meishan pigs, in: Proceedings of the 6th World Congress on Genetics Applied to Livestock Production, 1998, Vol. 26, Armidale, pp. 478-481.

[25] Neumaier A., Groeneveld E., Restricted maximum likelihood estimation of covariances in sparse linear models, Genet. Sel. Evol. 30 (1998) 3-26. 
[26] Nezer C., Moreau L., Brouwers B., Coppieters W., Detilleux J., Hanset R., Karim L., Kvasz A., Leroy P., Georges M., An imprinted QTL with major effect on muscle mass and fat deposition maps to the IGF2 locus in pigs, Nat. Genet. 21 (1999) 155-156.

[27] Ovilo C., Pérez-Enciso M., Barragan C., Clop A., Rodriguez C., Oliver M.A., Toro M.A., Noguera J.L., A QTL for intramuscular fat and backfat thickness is located on porcine chromosome 6, Mamm. Genome 11 (2000) 344-346.

[28] Paszek A.A., Wilkie P.J., Flickinger G.H., Rohrer G.A., Alexander L.J., Beattie C.W., Shook L.B., Interval mapping of growth in divergent swine cross, Mamm. Genome 10 (1999) 117-122.

[29] Patterson H.D., Thompson R., Recovery of inter-block information when block sizes are unequal, Biometrika 58 (1971) 545-554.

[30] Pérez-Enciso M., Varona L., Quantitative trait loci mapping in $\mathrm{F}_{2}$ crosses between outbred lines, Genetics 155 (2000) 391-405.

[31] Pérez-Enciso M., Clop A., Noguera J.L., Ovilo C., Coll C., Folch J.M., Babot D., Estany J., Oliver M.A., Diaz I., Sanchez A., A QTL on pig chromosome 4 affects fatty acid metabolism: evidence from an Iberian by Landrace intercross, J. Anim. Sci. 78 (2000) 2525-2531.

[32] Rohrer G.A., Alexander L.J., Keele J.W., Smith T.P.L., Beattie C.W., A microsatellite linkage map of the porcine genome, Genetics 136 (1994) 231-245.

[33] Rohrer G.A., Alexander L.J., Hu Z., Smith T.P.L., Keele J.W., Beattie C.W., A comprehensive map of the porcine genome, Genome Res. 6 (1996) 371-391.

[34] Rohrer G.A., Keele J.W., Identification of quantitative trait loci affecting carcass composition in swine: I. Fat deposition traits, J. Anim. Sci. 76 (1998) 2247-2254.

[35] Rothschild M.F., Liu H.C., Tuggle C.K., Yu T.P., Wang L., Analysis of pig chromosome 7 genetic markers for growth and carcass performance traits, J. Anim. Breed. Genet. 112 (1995) 341-348.

[36] Walling G.A., Archibald A.L., Visscher P.M., Haley C.S., Mapping of quantitative trait loci on chromosome 4 in a Meishan $\times$ Large White Meishan pig F2 population, in: Proceedings of the 6th World Congress on Genetics Applied to Livestock Production, 1998, Vol. 23, Armidale, pp. 519-522.

[37] Walling G.A., Visscher P.M., Andersson L., Rothschild M.F., Wang L., Moser G., Groenen M.A.M., Bidanel J.P., Cepica S., Archibald A., Geldermann H., de Koning D.J., Milan D., Haley C.S., Combined analyses of data from QTL mapping studies: chromosome 4 effects on porcine growth and fatness, Genetics 155 (2000) 1369-1378.

[38] Wang L., Yu T.P., Tuggle C.K. Liu H.G., Rothschild M.F., A directed search for quantitative trait loci on chromosomes 4 and 7 in the pig, J. Anim. Sci. 76 (1998) 2560-2567.

[39] Weller J.I., Wiggans G.R., van Raden P.M., Ron M., Application of a canonical transformation to detection of quantitative trait loci with the aid of genetic markers in a multi-trait experiment, Theor. Appl. Genet. 92 (1996) 998-1002.

[40] Yu T.P., Wang L., Tuggle C.K., Rothschild M.F., Mapping genes for fatness and growth on pig chromosome 13: A search in the region close to the pig PIT1 gene, J. Anim. Breed. Genet. 116 (1999) 281-288. 